\title{
Constitutional guarantees generate negative externalities for the brazilian health system
}

Garantias constitucionais e a geração de externalidades negativas no sistema de saúde brasileiro.

Constitucionalidad de la creación de las externalidades externas para el sistema sanitario del sistema sanitario

Maria Célia Delduque ${ }^{1}$

\begin{abstract}
: objective: we aimed to know the legal demands on health and the arguments made by the patient, the defense, and the judge in judicial hearings. Methods: For this, we used the method of case law research. The research unit was Brazilian judicial processes with the material object of health demands, decided between 2012 and 2013. Results: The results showed reliance on constitutional arguments for both the request and the decision, while the defense was based on diverse and obsolete legal points. Conclusión: it was concluded that judges have decided questions about health using purely legal arguments and reproducing points made by the patient. The defense of the Brazilian health system is fragile due to the lack of an adequate legal rationale.

Keywords: Judicialization. Court decision. Public Health.
\end{abstract}

RESUMO: objetivo: conhecer as demandas judiciais sobre saúde e discursos do paciente, da defesa e do juiz da causa. Metodologia: utilizou-se o método da pesquisa jurisprudencial, levantando-se nos 27 tribunais brasileiros os processos cujo objeto material fosse demandas sobre saúde, decididos em 2012 e 2013. Resultados: os resultados demonstraram uma manutenção nos argumentos constitucionais para a solicitação e para a decisão, enquanto que a defesa do sistema de saúde tem elegido a teses jurídicas dispersas e obsoletas. Conclusão: os juízes têm decidido questões sobre saúde utilizandose de argumentos meramente jurídicos e repetidos do paciente. A defesa do sistema de saúde brasileiro é frágil em função dos inócuos argumentos trazidos para os autos.

Palavras-chave: Judicialização. Decisão judicial, Saúde pública.

RESUMEN: objetivo: conocer las demandas legales sobre la salud y los argumentos del paciente, la defensa y el juez en audiencias judiciales. Métodos: se utilizó el método de investigación de jurisprudencia. La unidad de investigación fue el proceso judicial brasileño con el objeto material de las demandas de salud, decidido entre 2012 y 2013 . Resultados: Los resultados mostraron dependencia de argumentos constitucionales tanto para la solicitud como para la decisión, mientras que la defensa se basó en puntos jurídicos diversos y obsoletos. Conclusión: se llegó a la conclusión de que los jueces han decidido cuestiones sobre la salud utilizando argumentos puramente legales y reproduciendo puntos

1 Pesquisadora da Fundação Oswaldo Cruz e Professora colaboradora da Universidade de Brasilia. E-mail: mcdelduque@gmail.com 
hechos por el paciente. La defensa del sistema de salud brasileño es frágil debido a la falta de un fundamento jurídico adecuado.

Palabras Ilave: Judicialización. Decisión judicial. Salud Pública

\section{Introduction}

Twenty years ago, the XXX World Health Assembly decided that, by the year 2000, people should have universal access to health worldwide. This decision reflected the certainty that the means to achieve this goal were available to most countries. Over the years, many countries have implemented far-reaching reforms in their health systems, following World Health Organization (WHO) guidelines, that have reached the intended target, although each with its own characteristics and pace.

A similar process has taken place in Brazil. In 1988, the country began to allocate more attention to health, and the government took a central role in making health the right of every citizen and a State duty. However, while on the one hand this political and social ideal was gradually taking shape as a constitutional right, it generated negative externalities that put at risk the very system (the Single Health System or SUS) created to universalize access to health. Collective health needs permeate the guarantee of this complex right. However, individual needs backed by the Constitution generate conflicts that ultimately find their way to the judiciary. This process, known as "judicialization of public health policies" lies at the heart of the negative externalities mentioned above.

This phenomenon has exponentially increased the number of judicial decisions that require the State to provide the most diverse goods and services requested in court by citizens. Each of these requests is based on individual needs, attested by the opinion of a medical practitioner. Such needs clash with health public policies established to meet the therapeutic needs of the entire Brazilian society, and based on reasonable data and priorities for choosing the best therapeutic alternatives for those who need them. The growing number of lawsuits demanding access to medicines, health products, and surgical and ICU beds, among others, creates a point of tension between the State and citizens whose right to health is guaranteed in the Constitution and in national laws. Although this judicialization pattern is known, there are no studies that quantify judicial demands of the public at the national level and qualify the discourse of the parties to this conflict. 
In this context, the present study was developed to answer the question: what are the judicial demands of citizens regarding health in Brazil, and what are the arguments of the procedural triad formed by the patient, the defense, and the judge in their individual roles?

\section{Methodology}

A retrospective study was undertaken with analytical description, with the analytical unit being the judicial health process, considering judgments issued in the entire country in the years 2012 and 2013.

The sample calculation shows simple random sampling, with a reliance level of about $95 \%$ and an error margin of $5 \%$. B is the sampling error and $\mathrm{Z}$ is the reliance level.

$$
n=\frac{N}{4(N-1) D+1}, \text { where } D=\frac{B^{2}}{Z_{a}^{2}}
$$

The criteria for inclusion in the sample were legal proceedings that contained claims for health services against the public health system-the Unified Health System (SUS). Exclusion criteria were processes with applications for health services against private health insurance. The sample was delimited to 996 cases. The total number of judicial documents analyzed was 2,988 , considering the application by the patient, the defense arguments, and the judge's final decision. Exploratory analysis of quantitative data was done using descriptive statistics, by generating frequency tables. For this analysis we used the Predictive Analytics Software (PASW), version 17.0.

Also, participant observation gave rise to numerous field report notes of observable detail in processes such as notes on the bottom of the page, single sheets and comments collected during the months of living with the file sectors of the legal proceedings in different courts state surveyed.

For qualitative analysis the Laurence Bardin ${ }^{1}$ method was initially used. To conduct lexical and syntactic analysis of the text of the discourse in our sample, we analyzed the total number of words and occurrences present in the studied documents, enabling ordinary frequencies according to the sense and syntactic aspects of sentence organization, revealing the discourse characteristics. 
The arguments were analyzed using Atienza's² Argumentation Theory.

\section{Results}

\section{Patient demands regarding health}

Patient health needs are reflected in judicial proceedings. Judicial requests for medications had significant predominance over other health inputs, accounting for 574 $(58 \%)$ of 996 cases analyzed (Figure 1). Among other demands, the most frequently expressed are ICU beds (11\% of cases), health products (9\%), and surgery (6\%) (Figure 1).

Figure 1 - Material content of the processes on health in Brazilian courts in 2012-2013

$$
100 \%=996
$$

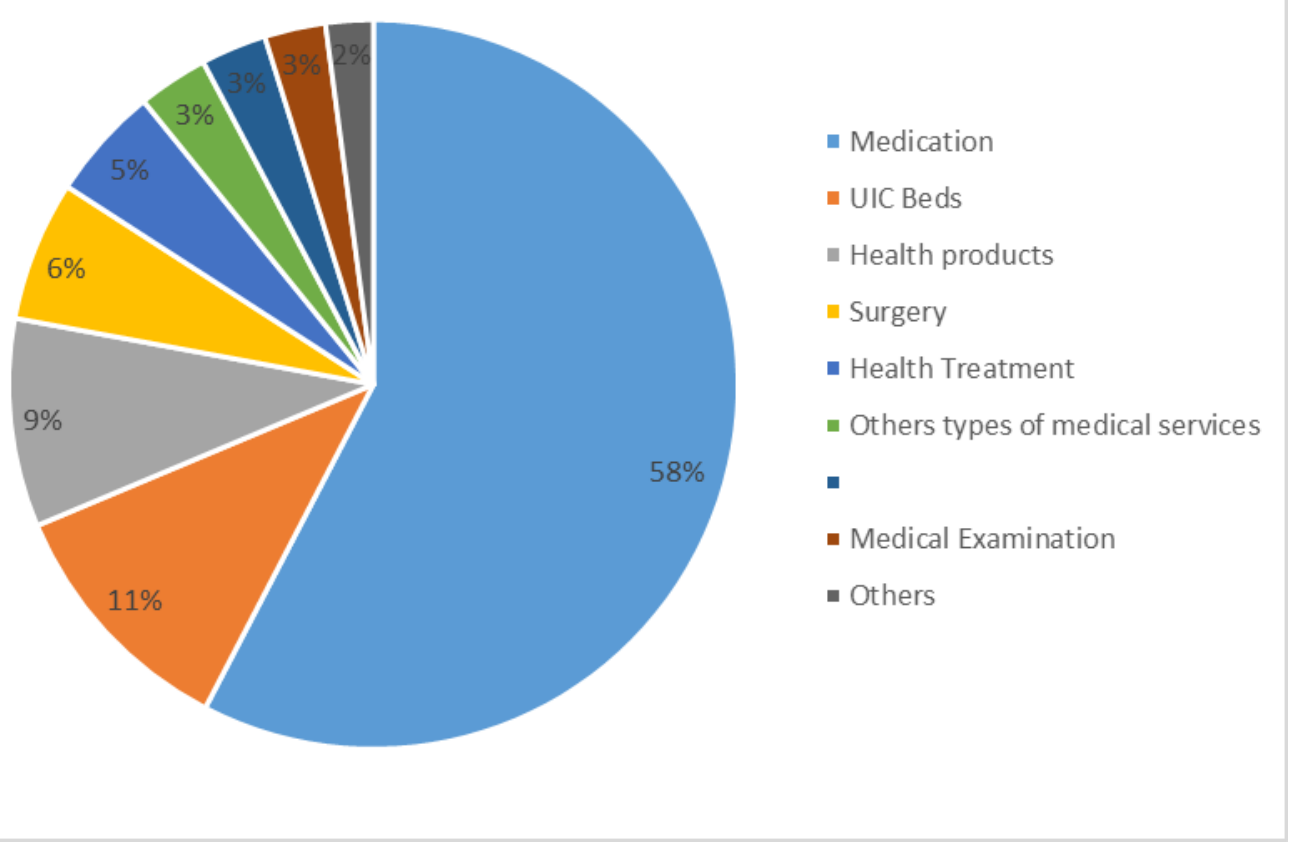

\section{Patient arguments used in lawsuits}

The arguments used by the patient can be divided into three main types: legal, personal, and administrative (Table 1). The legal arguments represent almost $45 \%$ of the total, and among these, the most frequent were those that made direct reference to the Federal Constitution $(679,18.6 \%)$. Other legal arguments included federal law 8080/90, 
state guidelines, and constitutional provisions. Personal arguments represented approximately $30 \%$ of the total, and usually included economic aspects and potential harm to the health of patients. Finally, administrative arguments represented approximately $17 \%$ of the total and included aspects regarding failure by the State in managing the assets of the public health sector.

Table 1 - Arguments used by patients in health lawsuits, 2012-2013

\begin{tabular}{l|c|c|c}
\hline Description of Patient's arguments & $\begin{array}{c}\text { Nature of } \\
\text { argument }\end{array}$ & Quantity & $\%$ \\
\hline Total & & 3,647 & 100 \\
\hline Articles of the Federal Constitution & Legal & 679 & $18.6 \%$ \\
\hline Poverty of patient & Personal & 626 & $17.2 \%$ \\
\hline Law 8080/90 & Legal & 368 & $10.1 \%$ \\
\hline Risk of worsening the patient's situation & Personal & 279 & $7.7 \%$ \\
\hline Principle of human dignity & Legal & 266 & $7.3 \%$ \\
\hline Articles of the State Constitution & Legal & 248 & $6.8 \%$ \\
\hline Negative for supply / treatment by & Administrative & 219 & $6.0 \%$ \\
\hline administrative channels & Personal & 208 & $5.7 \%$ \\
\hline Risk of patient death & Legal & 180 & $4.9 \%$ \\
\hline Jurisprudence & Administrative & 179 & $4.9 \%$ \\
\hline Medication/input/treatment costs too much & Legal & 109 & $3.0 \%$ \\
\hline Right to health must be fully guaranteed & Administrative & 81 & $2.2 \%$ \\
\hline Medication/input/treatment unavailable & Administrative & 64 & $1.8 \%$ \\
\hline Lack of beds in the ICU & Administrative & 54 & $1.5 \%$ \\
\hline $\begin{array}{l}\text { Ineffectiveness of the } \\
\text { drug/input/standardized treatment }\end{array}$ & Administrative & 51 & $1.4 \%$ \\
\hline Limited budget & Administrative & 36 & $1.0 \%$ \\
\hline Exhausted administrative channels & & & \\
\hline
\end{tabular}

\section{Defense arguments}

We were also able to divide the defense arguments into 3 types, including those related to judicial doctrine, to administrative rules, and to the law itself (Table 2). However, the largest single proportion of arguments (25.1\%) came under the definition of "principle of human dignity," a category that included highly fragmented theses developed by the defense in their representation (data not shown). Judicial doctrine arguments represented $37.5 \%$ of the total and included principles of law and legal dogma. The administrative 
arguments constituted $33.8 \%$ of the total, including economic theses, and logistical and procedural aspects. Finally, only one type of argument (3.5\% of the total) was of a legal nature and called for jurisprudence.

Table 2 - Arguments of the defense used in health lawsuits, 2012-2013

\begin{tabular}{|c|c|c|c|}
\hline $\begin{array}{l}\text { Description of defense } \\
\text { arguments }\end{array}$ & $\begin{array}{l}\text { Nature of } \\
\text { argument }\end{array}$ & Quantity & $\%$ \\
\hline Total & & 2,123 & 100 \\
\hline Law & Legal & 533 & $25.1 \%$ \\
\hline Passive illegitimacy of the State & Legal & 233 & $11.0 \%$ \\
\hline $\begin{array}{l}\text { Drug/input/treatment must be } \\
\text { replaced by others }\end{array}$ & Administrative & 210 & $9.9 \%$ \\
\hline $\begin{array}{l}\text { Drug/input/treatment nonstardardized by } \\
\text { SUS }\end{array}$ & Administrative & 209 & $9.8 \%$ \\
\hline Principle of completeness & Legal & 154 & $7.3 \%$ \\
\hline $\begin{array}{l}\text { Theory of Reserve for } \\
\text { Contingencies* }\end{array}$ & Legal & 134 & $6.3 \%$ \\
\hline No reason for the action & Legal & 125 & $5.9 \%$ \\
\hline $\begin{array}{l}\text { Drug/input/treatment standardized } \\
\text { by SUS }\end{array}$ & Administrative & 122 & $5.7 \%$ \\
\hline Default & Legal & 115 & $5.4 \%$ \\
\hline Budget & Administrative & 89 & $4.2 \%$ \\
\hline Jurisprudence & Legal & 75 & $3.5 \%$ \\
\hline $\begin{array}{l}\text { Federal Government has the } \\
\text { responsibility to reimburse } \\
\text { oncology drugs }\end{array}$ & Administrative & 49 & $2.3 \%$ \\
\hline $\begin{array}{l}\text { Drug/input/treatment requested is } \\
\text { provided by SUS }\end{array}$ & Administrative & 39 & $1.8 \%$ \\
\hline $\begin{array}{l}\text { Serious injury to the social and } \\
\text { economic order }\end{array}$ & Legal & 36 & $1.7 \%$ \\
\hline
\end{tabular}

*The theory of Reserve for Contingencies was developed by the German Constitutional Court in the year 1970, affirming that citizens can only require of the State what could reasonably be expected.

\section{Arguments applied by the judge}

Judges often resorted to judicial doctrine and the letter of the law (87\%) as the basis for their decisions (Table 3). Among these arguments, the most frequent made reference to the Brazilian Federal Constitution (23.7\%), followed by jurisprudence, and Federal Law $8080 / 90$, representing $10 \%$ of the total. 
Table 3 - Arguments made by the judge in deciding health lawsuits, 2012-2013

\begin{tabular}{l|c|c|c}
\hline Description of judge's argument & $\begin{array}{c}\text { Nature of } \\
\text { argument }\end{array}$ & Quantity & $\%$ \\
\hline Total & & 2.555 & 100 \\
\hline Articles of the Federal Constitution & Legal & 606 & $23.7 \%$ \\
\hline Jurisprudence & Legal & 272 & $10.6 \%$ \\
\hline Trials extinction without the verdict & Legal & 266 & $10.4 \%$ \\
\hline Organic Law on Health 8080/90 & Legal & 262 & $10.3 \%$ \\
\hline Evidence of the necessity for the application & Legal & 224 & $8.8 \%$ \\
\hline Health is everyone's right & Legal & 168 & $6.6 \%$ \\
\hline Default & Legal & 141 & $5.5 \%$ \\
\hline Joint responsibility of the federal entities & Legal & 123 & $4.8 \%$ \\
\hline Articles of the State Constitution & Legal & 122 & $4.8 \%$ \\
\hline Principle of completeness & Legal & 102 & $4.0 \%$ \\
\hline Patient death & Personal & 74 & $2.9 \%$ \\
\hline Legal literature & Legal & 63 & $2.5 \%$ \\
\hline Right to health must be fully guaranteed & Legal & 62 & $2.4 \%$ \\
\hline No reason for action object & Legal & 41 & $1.6 \%$ \\
\hline Protocols and official lists & Administrative & 21 & $0.8 \%$ \\
\hline Theory of Reserve for Contingencies & Legal & 8 & $0.3 \%$ \\
\hline
\end{tabular}

\section{Discussion}

In this nationwide assessment of legal demands regarding public health, we found that patients frequently focus their demands on the right to free medicine, ICU beds, medical examinations, and other procedures. Requests for drugs were more frequent than all other requests together. Some local studies 3, 4, 5, 6 also found a higher concentration of legal demands for drugs. Medication should be offered for free to the public, in this understanding of the Constitution, and when the health system fails to do so, lawsuits ensue.

Patient demands often offer arguments such as the risk of worsening patient health, economic poverty, as well as legal and constitutional aspects that guarantee the universal right to health. A personal medical doctor always lends support to personal and diseaserelated arguments with reports and prescriptions (data not shown). In none of the cases evaluated did the defense request an expert opinion on the validity of these reports and prescriptions (data not shown). Economic arguments tried to demonstrate an individual's 
lack of resources for the purchase of medication or treatment. This finding indicates that a contingent of poor people have been going to court to plead for health services. The fact that the public first resorted to arguments regarding the law or judicial doctrine suggests that for citizens the law carries a political and moral force in favor of their demands.

Defense arguments were often fragile and fragmented. Without a strong central thesis to convince the judges, the State almost never wins cases against patients. In support of the idea that state defenders fail to promote effective points, judges frequently resort to the Constitution, reproducing the plaintiffs' arguments and ignoring the defense. Only a small percentage of judges demonstrated concern about the potential death of the patient. Other studies also show that the judge's decision is based on the legal text without considering aspects of public health $7,8,9,10$.

The right to social benefits, notably to universal health, guaranteed in the Constitution and federal laws, has generated the negative externality called judicialization of health public policies. Brazilian ideals of social justice and the right to health have created incentives for the individual citizen to go to court, putting at risk the viability of the very system established to help citizens in the first place. It is advisable that countries moving towards a reformulation of their health system look to the Brazilian model for potential hidden costs. On the other hand, it is paramount that the public defense system develops a more coordinated response to the increasing instances of legal demands against the Brazilian State.

\section{References}

1 - Bardin, L. Análise de Conteúdo. São Paulo: Almedina Brasil; 2011

2 - Atienza,M. O Direito como Argumentação. Lisboa: Escolar, 2014

3 - Menicucci, TMG; Machado, JA. Judicialization of health policy in the definition of access to public goods: individual rights versus collective rights. Brazilian. Political Science. Review. [online]. 2010, vol.5 Selected edition, pp. 33-68.

4 - Trevisan, L M et al. Access to treatment for phenylketonuria by judicial means in Rio Grande do Sul, Brazil. Ciência e saúde coletiva [online]. 2015, vol.20, n.5, pp. 1607-1616.

5. Sant'ana, João Maurício Brambati; PEPE, Vera Lúcia Edais; OSORIO-DE-CASTRO, Claudia Garcia Serpa and VENTURA, Miriam. Essencialidade e assistência farmacêutica: 
considerações sobre o acesso a medicamentos mediante ações judiciais no Brasil. Rev Panam Salud Publica [online]. 2011, vol.29, n.2, pp. 138-144.

6. GOMES, Fernanda de Freitas Castro et al. Acesso aos procedimentos de média e alta complexidade no Sistema Único de Saúde: uma questão de judicialização. Cad. Saúde Pública [online]. 2014, vol.30, n.1, pp. 31-43.

5 - Biehl J, Amon JJ, Socal MP, Petryna A. Between the court and the clinic: lawsuits for medicines and the right to health in Brazil. Health Hum Rights 2012; 14(1):E36-52.

6 - Biehl J, Petryna A, Gertner A, Amon JJ, Picon PD. Judicialisation of the right to health in Brazil. Lancet. 2009 Jun 27; 373(9682):2182-4. doi: 10.1016/S0140-6736(09)61172-7 7 - Yamin AE. Editorial: promoting equity in health: what role for courts? Health Hum Rights;16(2): E1-9, 2014

8 - Vargas-Peláez CM; Rover MR; Leite SN; Rossi Buenaventura F; Farias MR. Right to health, essential medicines, and lawsuits for access to medicines--a scoping study. Social Science and Medicine;121:48-55, 2014 Nov.

9 - Guimarães R. Technological incorporation in the Unified Health System (SUS): the problem and ensuing challenges. Cien Saude Colet; 19(12):4899-908, 2014 Dec.

10 - Gomes Fde F; Cherchiglia ML; Machado CD; Santos VC; Acurcio Fde A; Andrade El. Access to medium and high-complexity procedures in the Brazilian Unified National Health System: a matter of judicialization. Cadernos de Saúde Pública; 30(1):31-43, 2014 Jan. 